\title{
Strategy for Implementing Elearning to Achieve Outcome-Based Education
}

\section{Muhammad Rozahi Istambul ${ }^{1 *}$, Azhar Arraniry Yustia $^{2}$, Andhieny Rachmatikasari ${ }^{3}$, Indra Armanda Putra ${ }^{4}$, Mochamad Ridwan Taufik Hidayat ${ }^{5}$}

\author{
Department of Information System, Widyatama University, Bandung, East Java, Indonesia \\ $1 *$ Rozahi.istambul@widyatama.ac.id, \\ ${ }^{3}$ Andhieny.rachmatikasari@widyatama.ac.id, \\ ${ }^{2}$ Azhar.arraniry@widyatama.ac.id, \\ ${ }^{4}$ Indra.armanda@widyatama.ac.id,
}

${ }^{5}$ Ridwan.taufik@widyatama.ac.id

Article History: Received:11 January 2021; Accepted: 27 February 2021; Published online: 5 April 2021

\begin{abstract}
Currently, the use of eLearning in education is increasingly playing a role, especially in universities. Thus, it is very important to innovate in designing optimal learning strategies. The meaning of optimization does not only mean that related activities: materials, forums, discussions, assignments, and quizzes that have been delivered by lecturers to students, but outcome-based education (OBE) from the courses delivered can be optimal effectively and efficiently in the learning process. [1]-[2]. As is known in general, universities in Indonesia will conduct lectures for 16 meetings following the implementation of mid-term and end-semester exams, which in the end all activities that have a component of their value will be recapitulated into the final score. This first method cannot be said that students have achieved optimal OBE [3]-[4] because students only carry out the obligations of lecturer assignments every week. In this case, students who have fulfilled their obligations cannot pass the material that has been delivered by the lecturer (pause) to gain additional knowledge, because students do not have the challenge to continue to the next material. This condition occurs because the lecturer next week again provides the material with obligations that must be done by students, and usually the latest topics do not continue the material on the previous topic. Another learning strategy is that the learning process does not have to refer to the completion of the 4-month meeting, but is given the opportunity for students to organize their own learning so that they can immediately reach the intended OBE. Of course, starting with the provision of several materials and targets that must be achieved so that students can creatively manage their own time by solving the problem. The weekly topic contains condensation of several topics that have been designed according to OBE. Furthermore, this study will compare the extent to which OBE optimization can occur in students between the two learning process models carried out by eLearning [5].
\end{abstract}

Keywords: eLearning strategy, optimization, learning model, outcome-based education

\section{Introduction}

The implementation of the learning process during the past year in all tertiary institutions in Indonesia has generally used eLearning. Higher education institutions make various efforts to continue to be able to interact between lecturers and students, from providing infrastructure to learning strategies. As is known, the higher education curriculum in Indonesia generally refers to the implementation time in one semester for approximately 4 months with details of 14 lecture meetings and 2 testing times, namely midterm and final semester exams. Meanwhile, the way of providing material, discussion, and assignment in the strategy learning process is almost the same as during conventional face-to-face meetings (not eLearning). The strategy referred to here is related to the implementation of eLearning, that the implementation time must still meet the number of 14 face-to-face meetings, in fact, several universities are implementing face-to-face meeting hours similar to the schedule in conventional times, which differ only in how to communicate using technological or nontechnological means.

Information technology is currently able to provide various learning needs, especially learning materials that have been carried out by lecturers. The experiences of lecturers who usually provide an overview for students can also be represented by the role of information technology, such as open educational resources (OER). In this strategy, the experience accessed by students will be more than just those conveyed by the lecturer, where the process of being able to repeat various materials or experiences will be easier for students to do whenever desired (according to convenience). Of course, this comfort problem will not be obtained when lecturers and students do it face-to-face, because of the limited time related to the delivery of material and experiences. Another problem that arises is that students cannot repeat what the lecturer has said so that they can recall the material that has been studied in the past. These various problems make limitations when the learning process is carried out face-to-face in conventional classrooms.

The current learning model uses information technology, meaning that the role of the interaction needs to be modified so that the use of information technology is optimal. Various things that must be achieved in the 
learning process, of course, need to be made strategies that are tailored to the capabilities of information technology. The strategies in question include, 1) time and duration of learning interactions, 2) discussion in the forum, 3) assignments or quizzes, in which all these activities will certainly affect the interaction between lecturers and students. A good strategy will certainly result in an optimal learning process, as the initial goal of the course is that students can get outcome-based education (OBE) that has been made according to the minimum standards of the subject concerned.

\section{Methodology}

The implementation of eLearning can be done in various ways, but this research will lead to outcome-based education that leads to student achievement. This OBE aims to enable students to acquire a competency by carrying out a case study completion on an ongoing basis following the course objectives [6]. The learning model is used as technical in the application of OBE, namely using a novel outcome-based education model [7], as illustrated below:

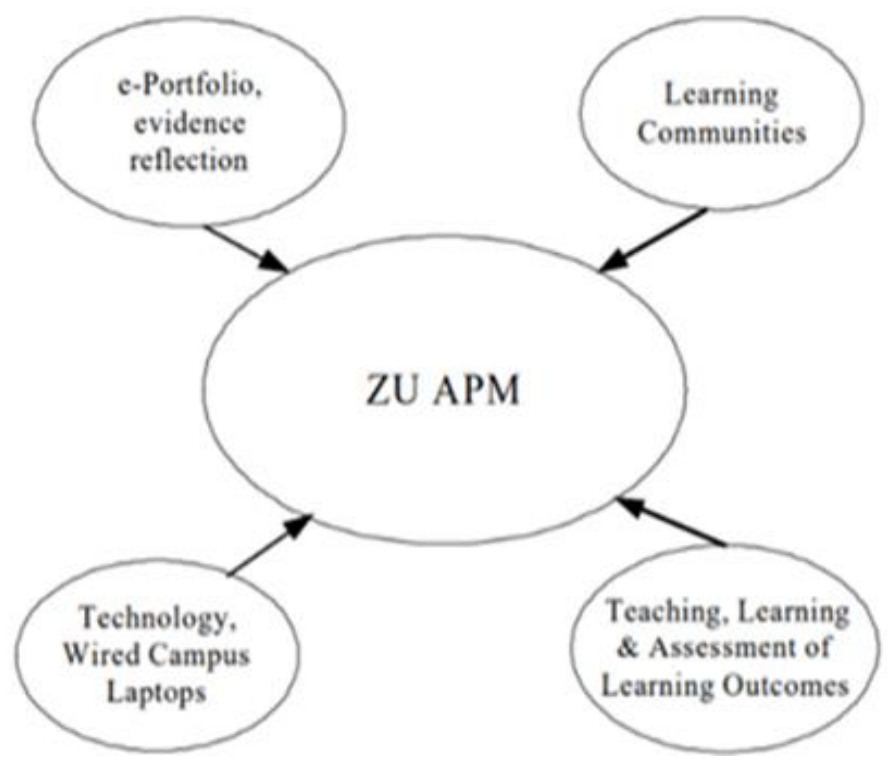

Figure 1. A novel outcome-based education model

OBE is of concern to researchers because the ability of students to trace various references is very easy to access, as are guidelines and understandings related to open educational resources (OER) [8]-[9]. In eLearning, there are so many references that will be solved problems in completing various assignments given by the lecturer, so that it is very possible for students to learn from these various references to be used as inspiration in completing their case studies [10]-[11].

\section{Results and Discussion}

This research was conducted in the engineering faculty of Widyatama University by involving several students in different classes with the same subject, which was divided into two groups, namely group one (class A) and group two (class B). The implementation of each lecture uses eLearning while the interaction strategy in the learning process is different, but all are directed at OBE. Each group will still be given the minimum required interaction guidelines for learning administration, namely material, discussion forums, assignments, and quizzes. The strategies that are running in each group can be analyzed, as follows:

\subsection{The first group}

Represented in class A which will focus on the learning process according to the minimum rules, with the technical rules of giving obligations and interactions following the meeting of 14 meetings and 2 testing times. Referring to the 14 meetings, it means that 14 materials are needed, along with assignments that will become the obligations of students. In this case, usually, the lecturer will prepare some material according to the topic of a course. Thus, the material is very broad and is still part of the course for completing various other case studies. 
The learning process is very flexible because the reference is fixed weekly, meaning that all interactions occur for one week to be completed immediately, especially the obligation for students who were previously lecturers who have facilitated the deadline for collection on the last day of each week. The time for discussion is also flexible because both lecturers and students in responding or responding are sufficient to write in the discussion forum and there is no need to wait for each other at the same time in real-time.

Meanwhile, from the point of view of student motivation, to complete an assignment or discussion in a discussion forum is actually very high, because every student will always refer to various literature on the internet (OER) to solve the problem. However, most of them only look for answers in several pieces of literature on the internet according to limited material. Furthermore, the results are presented in a discussion forum by answering the assignments given by the lecturers. In this case, students cannot go beyond the limited knowledge of lecturer material, while students can gain further than just the material and assignments delivered by the lecturer. The discussion limitations in the material and discussion forums and assignments are only limited to the topics of the part of the course that the OBE has planned. Thus, the learning outcomes that were achieved within a span of 4 months for students, OBE results could only be achieved during 16 interaction meetings with various case studies that were not integrated (sustainable).

\subsection{The second group}

Represented in class B which also uses a learning process based on minimum rules, but the total number of meetings in one semester does not have to be completed by students for 14 meetings to reach OBE, so the lecturer will provide several materials which are usually for 3 or 4 discussions to be once every week. Even in the following week, the amount of material may change, along with the development of student knowledge that appears during discussion forums and assignments.

The learning process that occurs is very flexible because the reference is to the student's ability to complete the discussion in the weekly material, meaning that the learning interaction for 1 week becomes very high in terms of students' efforts to complete their obligations, by looking for various problem-solving references on the internet (OER). The discussion forum will be more specific considering that there are more and more discussions, so it appears that students have indirectly integrated one material with the next in a unit of time. Such a model, of course, can motivate students because based on the directions given by the lecturer, the higher it is and the ease of obtaining several references on the internet (OER).

Regarding the learning model strategy like this leads to an outcome that has been determined the result, but by providing case studies that will be related to each other from each weekly meeting. The difference with the learning model in the first group is that the material provided by the lecturer every week does not discuss in detail the weekly topics as described in the first model. However, the weekly material only takes part in the topics that are directly related to the previous material and have something to do with the case studies given to students.

The tentative conclusion regarding the learning approach in the two groups above is that the first learning strategy is to discuss 14 different topics each week, an example of case studies will be given according to that topic. However, it is often not integrated between one topic and another and will have an impact on the completion of the case study. This is because the discussion of each topic is very detailed, so the case studies to be discussed will also be completed in different ways, adjusted for the details of the weekly topics. Meanwhile, students in the second group will be more focused and specific in understanding each material. However, the material referred to is only a certain section because the material in that section is only related to a case study that is being completed in stages/continuously. So it can be seen that the material prepared by the lecturers of each group refers to the same topic of discussion in a course, but the OBE strategy regarding the description of the material is different.

Following are the results of the analysis of the learning process described in the following table regarding the comparison of the two group approaches. 
Table 1. The results of the analysis of the first group

\begin{tabular}{|c|c|c|c|c|c|c|c|}
\hline \multirow[b]{2}{*}{ No. } & \multirow[b]{2}{*}{ Student } & \multicolumn{5}{|c|}{ Student Activities } & \multirow{2}{*}{$\begin{array}{c}\text { Assessment of all activities } \\
\text { of each student }\end{array}$} \\
\hline & & $\begin{array}{l}\text { Discussion } \\
\text { forum } \\
(\%)\end{array}$ & $\begin{array}{c}\text { Suistanable (S) or } \\
\text { Independent (I) } \\
\text { work }\end{array}$ & $\begin{array}{c}\begin{array}{c}\text { Completion of } \\
\text { group work } \\
(\%)\end{array} \\
\end{array}$ & $\begin{array}{c}\text { Quiz work } \\
(\%)\end{array}$ & $\begin{array}{c}\text { Duration of } \\
\text { OBE } \\
\text { completion } \\
\text { (weeks) }\end{array}$ & \\
\hline 1 & S-1 & 85 & I & 95 & 100 & 16 & $\mathbf{E}$ \\
\hline 2 & $\mathrm{~s}-2$ & 95 & I & 100 & 100 & 16 & $\mathbf{E}$ \\
\hline 3 & S-3 & 80 & I & 95 & 100 & 16 & $\mathbf{E}$ \\
\hline 4 & $\mathrm{~S}-4$ & 90 & $\mathbf{I}$ & 100 & 100 & 16 & $\mathbf{E}$ \\
\hline 5 & S-5 & 90 & I & 95 & 95 & 16 & $\mathbf{E}$ \\
\hline 6 & S-6 & 85 & I & 100 & 100 & 16 & $\mathbf{E}$ \\
\hline 7 & s-7 & 96 & I & 100 & 100 & 16 & $\mathbf{U}$ \\
\hline 8 & S-8 & 85 & I & 100 & 100 & 16 & $\mathbf{E}$ \\
\hline 9 & S-9 & 87 & I & 95 & 90 & 16 & $\mathbf{E}$ \\
\hline 10 & S-10 & 94 & I & 100 & 100 & 16 & $\mathbf{E}$ \\
\hline 11 & S-11 & 87 & I & 95 & 100 & 16 & $\mathbf{E}$ \\
\hline 12 & S-12 & 87 & I & 95 & 100 & 16 & $\mathbf{E}$ \\
\hline 13 & S-13 & 92 & I & 95 & 95 & 16 & $\mathbf{E}$ \\
\hline 14 & S-14 & 93 & I & 95 & 100 & 16 & U \\
\hline 15 & S-15 & 85 & I & 90 & 95 & 16 & $\mathbf{E}$ \\
\hline 16 & S-16 & 90 & I & 90 & 95 & 16 & $\mathbf{E}$ \\
\hline 17 & S-17 & 94 & I & 95 & 100 & 16 & E \\
\hline 18 & S-18 & 97 & I & 100 & 100 & 16 & U \\
\hline 19 & S-19 & 87 & I & 90 & 95 & 16 & E \\
\hline 20 & $\mathrm{~s}-20$ & 80 & I & 95 & 95 & 16 & E \\
\hline
\end{tabular}

In Table 1., it appears that the average discussion of material during the discussion forum was around $88.95 \%$ and what happened at that time was that the discussion was generally limited to material from the topic per week that was delivered. Only a few students discussed the achievements of the material given and in general, it was only limited to the achievements of the material presented $(\mathrm{E})$. As the outcome is expected based on outcome-based education at week 16 with case resolution that is not integrated.

Table 2. The results of the analysis of the second group

\begin{tabular}{|c|c|c|c|c|c|c|c|}
\hline \multirow[b]{2}{*}{ No. } & \multirow[b]{2}{*}{ Student } & \multicolumn{5}{|c|}{ Student Activities } & \multirow{2}{*}{\begin{tabular}{|c|}
$\begin{array}{c}\text { Assessment of all activities of } \\
\text { each student }\end{array}$ \\
$\begin{array}{l}\text { Outcome-Based Education } \\
\text { (less-L/equal-E/surpass-U) }\end{array}$
\end{tabular}} \\
\hline & & $\begin{array}{l}\text { Discussion } \\
\text { forum } \\
(\%)\end{array}$ & $\begin{array}{c}\text { Suistanable (S) or } \\
\text { Independent (I) } \\
\text { work }\end{array}$ & $\begin{array}{c}\text { Completion of } \\
\text { group work } \\
(\%)\end{array}$ & $\begin{array}{c}\text { Quiz } \\
\text { work (\%) }\end{array}$ & $\begin{array}{l}\text { Duration of } \\
\text { OBE } \\
\text { completion } \\
\text { (weeks) }\end{array}$ & \\
\hline 1 & S-1 & 95 & $S$ & 97 & 100 & 9 & $\mathrm{U}$ \\
\hline 2 & S-2 & 97 & $\mathrm{~S}$ & 100 & 100 & 8 & $\mathrm{U}$ \\
\hline 3 & S-3 & 92 & $\mathrm{~S}$ & 100 & 100 & 9 & $\mathrm{U}$ \\
\hline 4 & $\mathrm{~S}-4$ & 90 & $\mathrm{~S}$ & 100 & 100 & 10 & $\mathrm{U}$ \\
\hline 5 & S-5 & 90 & $\mathrm{~S}$ & 100 & 100 & 10 & $\mathrm{U}$ \\
\hline 6 & S-6 & 92 & $\mathrm{~S}$ & 100 & 100 & 9 & $\mathrm{U}$ \\
\hline 7 & S-7 & 96 & $\mathrm{~S}$ & 100 & 100 & 8 & $\mathbf{U}$ \\
\hline 8 & S-8 & 95 & $\mathrm{~S}$ & 100 & 100 & 8 & $\mathrm{U}$ \\
\hline 9 & S-9 & 85 & $\mathrm{~S}$ & 97 & 95 & 10 & $\mathrm{U}$ \\
\hline 10 & S-10 & 94 & $\mathrm{~S}$ & 100 & 100 & 8 & $\mathrm{U}$ \\
\hline 11 & S-11 & 97 & $\mathrm{~S}$ & 100 & 100 & 8 & U \\
\hline 12 & S-12 & 94 & $\mathrm{~S}$ & 100 & 100 & 9 & $\mathrm{U}$ \\
\hline 13 & S-13 & 87 & $\mathrm{~S}$ & 100 & 100 & 10 & $\mathbf{U}$ \\
\hline 14 & S-14 & 95 & $\mathrm{~S}$ & 100 & 100 & 9 & U \\
\hline 15 & S-15 & 90 & $\mathrm{~S}$ & 95 & 100 & 9 & $\mathrm{U}$ \\
\hline 16 & S-16 & 93 & $\mathrm{~S}$ & 100 & 100 & 8 & $\mathbf{U}$ \\
\hline 17 & S-17 & 95 & $\mathrm{~S}$ & 100 & 100 & 8 & $\mathrm{U}$ \\
\hline 18 & S-18 & 87 & $\mathrm{~S}$ & 100 & 100 & 9 & U \\
\hline 19 & S-19 & 90 & $\mathrm{~S}$ & 95 & 95 & 8 & U \\
\hline 20 & S-20 & 90 & $\mathrm{~S}$ & 100 & 95 & 9 & $\mathrm{U}$ \\
\hline
\end{tabular}

Whereas in Table 2, it appears that the average discussion of material during the discussion forum is around 92.2\% and the discussion is more in-depth than the first group, on average students combine various weekly materials that occur in the first group. The result can be seen that the achievement of outcome-based education for almost all students achieves it, meaning that the ability of the material given is achieved (U). Time to complete outcome-based education was also a mean of 8.8 weeks with completion of the continuous (integrative) case study.

\section{Conclusion}

Based on the results of the study which was applied in 2 different classes, it appears that the strategy used to obtain good outcome-based education requires a special strategy. In this case, it is necessary to focus on a subject topic, but not to cover the entire description of the topic. Technically, by selecting/arranging the appropriate material in the topic associated with case studies that will be assigned to students on an ongoing basis. So that students can still focus on completing their assignments, and take their references (OER) which 
are also following the discussion material from the lecturer. The optimal results related to OBE are expected following the example of the second group learning because in addition to producing OBE it is also efficient and effective in the learning process in preparing case studies on an ongoing basis.

\section{References}

1. Harden, R. M. (2007). Outcome-based education: the future is today. Medical teacher, 29(7), 625-629.

2. Akella Pathanjali Sastri, Jammula Lakshmi Narayana, Kamisetty Nageswara Rao, "Outcome Based Education from Capability Maturity Model Perspective", International Journal of Science and Research, Volume 8, Issue 2, 2019.

3. Mohamed Sayed, Faris Baker, "E-Learning Optimization Using Supervised Artificial NeuralNetwork", Journal of Software Engineering and Applications, 8, 26-34, 2015.

4. Andrew Martin," How to Optimize Online Learning in the Age of Coronavirus (COVID-19): A 5-Point Guide for Educators", https://newsroom.unsw.edu.au/news/social-affairs/how-optimise-onlinelearning-age-coronavirus, 2020.

5. Meng-Jung Tsai, "The Model of Strategic e-Learning: Understanding and Evaluating Student eLearning from Metacognitive Perspectives”, Educational Technology \& Society, 12(1), 34-48, 2009.

6. Yasemin Gulbahar, Filiz Kalelioglu, "Competencies for e-Instructors: How to Qualify and Guarantee Sustainability", Contemporary Educational Technology, 6(2), 140-154, 2015.

7. Bouslama, F., Lansari, A., Al-Rawi, A. M., \& Abonamah, A. A. (2003). A novel outcome-based educational model and its effect on student learning, curriculum development, and assessment. Journal of Information Technology Education: Research, 2(1), 203-214.

8. Peppino Franco Liviana Marinescu, Ines Benhold, John Kearns, David Brady, Esko Luis, Kati Valtonen, Piet Kommers, "Guidebook on Open Educational Resources (OER)", https://www.researchgate.net/publication/332936553_Guidebook_on_Open_Educational_Resources_O ER, 2019.

9. Schaffert, S., \& Geser, G. (2008). Open educational resources and practices. eLearning Papers, 7, 1419.

10. Tariq Sheakh, "E-Learning for Higher Education. A Case Study", Journal of Dynamical and Control Systems 10(04):1539-1545, 2018.

11. Jolene Skordis-Worrall, Hassan Haghparast-Bidgoli, "Learning Online: A Case Study Exploring Student Perceptions and Experience of a Course in Economic Evaluation", International Journal of Teaching and Learning in Higher Education, Volume 27, Number 3, 413-422, 2015. 